\title{
Research on Startup Competence of Returned Rural Migrant Workers
}

\author{
Dan Yang \\ School of Management \\ China West Normal University \\ Nanchong, China 637002
}

\begin{abstract}
To promote rural migrant workers for business startup at home town is one of the important way for developing rural economy in the country. During the business startup, the competences that rural migrant workers hold play a significant and basic role. Based on theories of business startup, this article takes rural migrant workers in Sichuan as an example and conducts relevant researches on the business startup of rural migrant workers through questionnaires and statistical analysis. The research results show, social practices and work experience are main sources of business startup for rural migrant workers, yet the business startup training that local authorities organize give little help to the formation and improvement of business startup. At the beginning of business startup, rural migrant workers have inherent shortage in the business startup, which however is partially improved through startup practice. Rural migrant workers are confident of the business startup of their own, in the meantime, the deficiencies in the business startup such as lack of continuous learning and innovation application will be barriers for their follow-up potentials of innovation, startup and development.
\end{abstract}

Keywords-startup competence; rural startup; returned rural migrant workers; Sichuan

\section{INTRODUCTION}

The economic income that farmers obtain through independent business startup is a necessary selection for modern rural and agricultural economic development in the country. As a key part for poverty reduction, income increase and job drive, the business startup of farmers play an important in reducing the urban-rural disparity. So to encourage farmers for business startup is a big deal to solve rural development problem in the country. The business startup that rural migrant workers launch at hometown is a developing trend under which labor resources are optimized for distribution in the country and also a crucial way to increase farmers' income and develop rural productivity, which has a special big significance in rural construction in the country.

At present, the business startups by returned rural migrant workers especially the new generation of rural migrant workers have been developing rapidly. Through working out of towns, rural migrant workers have not only accumulated funds for business startup but also have themselves improved

Supported by the Fundamental Research Funds of China West Normal University (Grant No. 17E010) in view, technique, management and marketing concept, which make it possible for them to succeed in business. After years of work in cities, what are the business startup competences that rural migrant workers have? Do they face shortage in competences during the business startup? What are the key points for rural migrant workers to improve for business startup? All of these still need corresponding researches.

\section{LITERATURE BACKGROUND}

Currently, business startup can be analyzed from two aspects, first, seen from individual characteristics, in the opinion of researchers, the business startup consists of two parts: party I, personal characteristics that a startup owner owns, some of which can be got through learning and training such as knowledge, skill and experience[1]; second, seen from the startup course, the business startup competences are thought shown through startup, and the startup tasks and actions a startup owner faces or take will vary with the business startup competence. The business startup competence includes individuality, skills and knowledge, regarded as a whole competence for a startup owner to exercise duties successfully (Chen, 1998) [2]. In the opinion of Lewis, H. (2011) [3], the business startup competence is thought a competence or potential qualified for a job; Diaz-Casero, J.C. (2012) [4] stressed the learning and understanding of startup competence; yet Muzychenko, O. (2008) [5], Lans, T. et al (2010) [6] stressed the abilities competent or qualified for a job, including professional skills and knowledge.

With regard to the startup dimension researches, De Noble(1999)[7] raised that it should include a skill mode with six dimensions such as developing innovative environment, skills to dispose and allocate key resources, interpersonal relationship, opportunity recognition, innovation and risk control; Man et al.(2002) [8] thought that the business startup competence should include organizational competence, relational competence, commitment competence, opportunity competence, strategic competence and conceptual competence. Based on the existing literatures as well as interviews with returned rural migrant workers in operation and management, this article divides the business startup competence into 9 dimensions including social activity, resource integration, and organizational operation, client service, interactive with clients, commitment persistence, teamwork cooperation and persisting learning. 
The business startup of rural migrant workers is a social and economic phenomenon that exists only in current stages in the country, on which Chinese scholars have conducted many researches. Liu Guangming and Song Hongyuan (2009)[9] thought that the business startup is a rational selection that rural laborers make after comparing the investment costs and benefits between input area and output areas. Wang Shengyuan (2009)[10] et al found that rural migrant workers should launch business startup through selectively developing agricultural operation or extended service on the basic of local resource endowment and regional advantages. Zhu Honggen (2010)[11] et al analyzed diverse factors that have obvious influences on the business startup of rural migrant workers. Zheng Shaofeng, Guo Quncheng (2010)[12] researched factors that influence the decision making of rural migrant workers from the west in the business startup, discovering that main factors stimulating rural migrant workers for business startup at home are their residence far from central cities and lack of social capitals. Analysis of the literatures show, currently most of researches related to the business startup of returned rural migrant workers are focused on startup environment, opportunities and willing, yet little attention is paid to the startup competences of rural migrant workers. Starting from the startup competence, this article, based on the questionnaires of returned rural migrant workers in Sichuan Province, investigates and analyzes the startup competence of the rural migrant workers in order to provide suggestions and references for improving the startup competence of rural migrant workers.

\section{RESEARCH DESIGN}

Based on recent literatures, this article makes a survey through questionnaires, from Sep to Oct 2017, a questionnaire was made on the business startup of returned rural migrant workers in Sichuan, five-point Likert scale method was adopted for all dimensions of business startup competences, statistics and tests show, Cronbach's alpha is 0.881, which turns out the questionnaire is rational, and the questionnaire data statistics are believable.

Among 118 returned rural migrant workers interviewed in startup, male workers account for $66.8 \%$, female workers $33.2 \%$, obviously male startup owners are predominant in the startup group; the startup industries mainly include catering $(74.5 \%)$, lease $(8.3 \%)$, crafts $(7.4 \%)$, accommodation $(3.2 \%)$, amusement service $(2.3 \%)$, local products $(2.6 \%)$ and stores (1.7\%). Seen from ages, those aged 21-30 account for $42.9 \%$, those aged $31-40$ account for $31.1 \%, 74.0 \%$ of the total; those aged $41-50$ account for $20.3 \%$ and others account from $5.7 \%$. The statistic data show, returned rural migrant workers who are young or grown are predominant in the business startup, which are consistent with the higher competences that they hold when working in cities.

\section{DATA ANALYSIS}

\section{A. Sources of Startup Competences}

Survey results show, there are diverse sources for the business startup competences of returned rural migrant workers, which mainly include social practice $(74.0 \%)$, work experience (53\%), accumulated knowledge (25.1\%) and instruction of successful entrepreneurs, and governmental startup training $(8.2 \%)$. Seen from the data above, the job attempts and work experiences of rural migrant workers in cities are the most important two channels for startup competence; however, the startup training organized by authorities almost fail to work, which turn out that social practice and work experience are of great importance for cultivating the startup competence, in the meantime, it is a reflection that the startup competence training organized by authorities is extremely inadequate and poor.

\section{B. Perceptual Analysis of Startup Competence}

First, with regard to the startup competence at the beginning of startup, $18.9 \%$ of recipients have competences of market opportunity recognition and development, $10.9 \%$ of recipients have expansion competence in social activity, and individuals owning competences of resource integration and utilization account for $15.2 \%$, yet those who are capable of organization and operation, client service, interaction with clients, commitment and persistence, teamwork cooperation and continuous learning account for $10 \%$ or less. The data above turn out that there is inherent deficiency of returned rural migrant workers in startup competence at the beginning of business startup.

Second, with regard to the recognition of startup competence importance, recipients consider that the most important startup competences are market opportunity and innovation $(17.3 \%)$, expansion in social activity $(17.3 \%)$ and resource integration and utilization (12.2\%), which are consistent with the competences the recipients have at the beginning of the business startup.

Third, based on summaries of self startup practice recipients have owned new understanding of the promotion that all dimensions have in the business startup, and the most important four factors are commitments and persistence $(17.3 \%)$, expansion in social activity $(16.5 \%)$, continuous learning $(11.2 \%)$, organization and operation (10.8\%). During the business startup, going with the continuous changes in internal and external circumstances, operators have to own persistence in order to run the business, keeping expansion and innovation to adapt to the market changes and persisting in learning to changing knowledge into competence. When encountering difficulties during the business startup, startup owners have to persist and run the business, which is the first factor for survival. In the meantime, social activities can be expanded to get more resources, and it will be practical for startup owners to keep learning to keep up with the market demands.

Fourth, from the initial business startup up to now, the recipients have three points improved greatly namely client service (20.0), resources integration and utilization (13.1\%), organization and operation $(11.0 \%)$, which reflect that during the business startup, repeated exercises will have relevant competences improved and upgraded.

Fifth, startup owners' competence improvement will be restricted by corresponding conditions. The survey shows, recipients say that the deficiencies in three points including 
expansion of social activity (21.7\%), commitment and persistence $(18.6 \%)$ and continuous learning (14.5\%) will kind of restrict the coming startup competence improvement, which are adverse to the success of continuous business startup. "Table I"

TABLE I. Startup COMPETENCE COGNITION OF RETURNED Migrant WORKERS StATISTICS

\begin{tabular}{|c|c|c|c|c|c|}
\hline $\begin{array}{l}\text { Startup Competence } \\
\text { Variable }\end{array}$ & $\begin{array}{c}\text { Initial } \\
\text { Competence } \\
\text { Proportion }(\%)\end{array}$ & $\begin{array}{c}\text { Competence } \\
\text { Importance } \\
\text { Cognition } \\
\text { Proportion (\%) } \\
\end{array}$ & $\begin{array}{c}\text { Actual } \\
\text { Competence } \\
\text { Efficiency } \\
\text { Proportion (\%) } \\
\end{array}$ & $\begin{array}{c}\text { Competence } \\
\text { Improvement } \\
\text { Proportion }(\%)\end{array}$ & $\begin{array}{c}\text { Competence } \\
\text { Improvement } \\
\text { Restriction } \\
\text { Proportion }(\%) \\
\end{array}$ \\
\hline $\begin{array}{l}\text { Market opportunity and } \\
\text { innovation }\end{array}$ & $18.9 \%$ & $17.3 \%$ & $6.0 \%$ & $5.3 \%$ & $5.9 \%$ \\
\hline Expansion in social activity & $10.9 \%$ & $17.3 \%$ & $16.5 \%$ & $5.3 \%$ & $21.7 \%$ \\
\hline $\begin{array}{l}\text { Resources integration and } \\
\text { utilization }\end{array}$ & $15.2 \%$ & $12.2 \%$ & $9.6 \%$ & $13.1 \%$ & $6.3 \%$ \\
\hline Organization and operation & $6.3 \%$ & $8.5 \%$ & $10.8 \%$ & $11.0 \%$ & $9.0 \%$ \\
\hline Client service & $9.6 \%$ & $6.6 \%$ & $8.8 \%$ & $20.0 \%$ & $4.1 \%$ \\
\hline Interaction with clients & $3.3 \%$ & $3.3 \%$ & $2.8 \%$ & $3.7 \%$ & $3.6 \%$ \\
\hline Commitment and persistence & $9.3 \%$ & $6.3 \%$ & $17.3 \%$ & $7.3 \%$ & $18.6 \%$ \\
\hline Teamwork cooperation & $9.3 \%$ & $9.6 \%$ & $9.6 \%$ & $7.8 \%$ & $2.7 \%$ \\
\hline Continuous learning & $6.3 \%$ & $7.0 \%$ & $11.2 \%$ & $9.0 \%$ & $14.5 \%$ \\
\hline
\end{tabular}

\section{Startup Competence Evaluation and Analysis}

1) Overall evaluation: Recipients who think they have sound overall startup competence, better: $8.1 \%$, good: $45.5 \%$, common: $42.4 \%$, bad or worse: $2.0 \%$. Seen overall, over half of the recipients are confident of the overall startup competence of their own.

During the questionnaires, recipients are required to evaluate the startup competence of their own through a tenpoint system (full point: 10), and the average points of startup owners' startup competence evaluated as per dimension are given in "Table II".

TABLE II. SELF-EVAluated PoINTS OF StARTUP COMPETENCE By RECIPIENTS

\begin{tabular}{|l|l|}
\hline \multicolumn{1}{|c|}{ Dimension } & Average Point (full point: 10) \\
\hline Market opportunity and innovation & 7.44 \\
\hline Expansion of social activity & 7.51 \\
\hline Resources integration & 7.52 \\
\hline Organization and operation & 7.91 \\
\hline Client service & 8.94 \\
\hline Interaction with clients & 8.58 \\
\hline Commitment and persistence & 8.14 \\
\hline Teamwork and cooperation & 8.41 \\
\hline Continuous learning & 8.03 \\
\hline
\end{tabular}

First client service, interaction with clients and teamwork and cooperation are at a good level, which indicates that the recipients have strong competences in the two aspects. During the business startup and operation, startup owners' competences in client service, communication with clients and interaction with clients are mighty important; in the meantime, the startup will need stronger teamwork and cooperation spirits, an excellent teamwork is a sound foundation for successful startup, so the recipients have higher competences in these two points. Second, the evaluation on persisting in commitments and continuous learning is higher as well. Any business startup is not a piece of cake, which needs confidence and courage for persistence; besides, startup owners and corporate members are required to keep learning new knowledge and skills to be applied in the business development. Third, the evaluations on market opportunity, innovation, expansion of social activity and resources integration, organization and operation are at a medium level, which reflect that recipients are dissatisfied at what they have performed, and there are still higher spaces for improvement for the three points.

2) Evaluation on startup competences as per dimension: As far as the dimensions related to the startup competence, recipients differ in data. Here four points including market opportunity and innovation, social activity and resources integration and utilization, client service and interaction with clients, commitment persistence, teamwork and cooperation and continuous learning are analyzed one by one.

First, with regard to the market opportunity and innovation, the average value of "find commercial opportunity and markets" and "develop and introduce new things and techniques" are lower, which turn out recipients have found that they are deficient in the two points. "Table III"

TABLE III. DESCRIPTIVE STATISTICS OF RECIPIENTS’ MARKET OPPORTUNITY AND INNOVATION

\begin{tabular}{|c|c|c|c|c|}
\hline Item & $\begin{array}{c}\text { Min } \\
\text { Value(M) }\end{array}$ & $\begin{array}{c}\text { Max } \\
\text { Value }(X)\end{array}$ & $\begin{array}{c}\text { Average } \\
\text { (E) }\end{array}$ & $\begin{array}{l}\text { Standard } \\
\text { Deviation }\end{array}$ \\
\hline $\begin{array}{l}\text { Find commercial } \\
\text { opportunity and market }\end{array}$ & 2.00 & 5.00 & 3.5100 & .81023 \\
\hline $\begin{array}{l}\text { Take challenges as } \\
\text { opportunities }\end{array}$ & 1.00 & 5.00 & 3.7300 & .94125 \\
\hline $\begin{array}{l}\text { Find clients' potential } \\
\text { demands }\end{array}$ & 2.00 & 5.00 & 3.7900 & 65590 \\
\hline $\begin{array}{l}\text { Develop and introduce new } \\
\text { things and technique }\end{array}$ & 1.00 & 5.00 & 3.5900 & .79258 \\
\hline $\begin{array}{l}\text { Increase new products and } \\
\text { service as per market } \\
\text { demands }\end{array}$ & 3.00 & 5.00 & 3.9800 & .66636 \\
\hline
\end{tabular}

Second, with regard to the social activity, resources integration, organization and operation, statistic data show, recipients have poor relations with those who control resources and power, yet keeping sound relations with clients. "Table IV" 
TABLE IV. DESCRIPTIVE STATISTICS OF RECIPIENTS' SOCIAL ACTIVITY, RESOURCES INTEGRATION, ORGANIZATION AND OPERATION

\begin{tabular}{|c|c|c|c|c|c|}
\hline Dimension & Description & Min Value (M) & Max Value (X) & Average (E) & $\begin{array}{l}\text { Standard } \\
\text { Deviation }\end{array}$ \\
\hline \multirow{4}{*}{ Social activity } & Keep sound relations with clients & 3.00 & 5.00 & 4.2900 & .71485 \\
\hline & Call friends for promotion & 1.00 & 5.00 & 3.7400 & 1.16879 \\
\hline & Find ways out and fund sources & 2.00 & 5.00 & 3.8400 & .86129 \\
\hline & Keep relations with those who have resources and power & 1.00 & 5.00 & 3.1600 & 1.20370 \\
\hline \multirow[t]{3}{*}{ Resource integration } & Make use of and introduce external resources & 1.00 & 5.00 & 3.7300 & .87450 \\
\hline & Rational allocation of personnel, properties and materials & 2.00 & 5.00 & 3.9300 & .83188 \\
\hline & Rapidly reconstruct resources to adapt to the market & 2.00 & 5.00 & 3.6100 & .83961 \\
\hline \multirow{3}{*}{$\begin{array}{l}\text { Organization } \\
\text { operation }\end{array}$} & Coordinate work tasks and interest relations & 2.00 & 5.00 & 3.8900 & 68009 \\
\hline & Adjust enterprise development strategies and thoughts & 3.00 & 5.00 & 4.0100 & .70345 \\
\hline & Redefine the enterprise development & 1.00 & 5.00 & 3.9600 & .81551 \\
\hline
\end{tabular}

Third, with regard to client service and interaction with during the client service practice, start owners have improved clients, statistic data show, most recipients are of higher selfevaluation, showing no obvious weakness, which turn out that all kinds of competence levels such as client service and interactions with clients. "Table V"

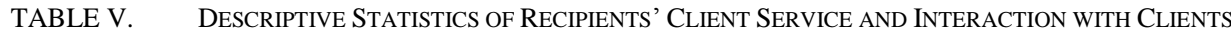

\begin{tabular}{|l|l|l|l|l|l|}
\hline \multicolumn{1}{|c}{ Dimension } & \multicolumn{1}{c|}{ Description } & Min Value (M) & Max Value (X) & Average (E) & $\begin{array}{c}\text { Standard } \\
\text { Deviation }\end{array}$ \\
\hline \multirow{2}{*}{ Client service } & Reply to and solve problems related to client service & 3.00 & 5.00 & 4.4500 \\
& Good suggestions to clients & 3.00 & 5.00 & 4.4800 \\
\cline { 2 - 6 } & Feedback from clients & 3.00 & 5.00 & 4.55922 \\
\hline \multirow{2}{*}{$\begin{array}{l}\text { Interaction } \\
\text { clients }\end{array}$} & with Find points shared with clients & 3.00 & 5.00 & 4.3500 \\
\cline { 2 - 6 } & Talk about hobbies with clients & 3.00 & 5.00 & 4.2600 \\
\cline { 2 - 6 } & Talk about daily life with clients & 2.00 & 5.00 & 4.2700 \\
\hline
\end{tabular}

Fourth, with regard to the commitment persistence, teamwork cooperation and continuous learning, recipients perform well, only poor in "apply what they have learned in startup" and "unceasingly raise new ideas and methods", which turn out that though the recipients do well in continuous

learning yet they are just staying in the stage of summaries, simulation and borrowing successful experience, but in the lack of applying new knowledge and skills they have obtained, which to some extent reflect that the business startup of rural migrant workers is in a simulation. "Table VI"

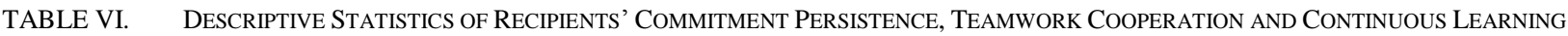

\begin{tabular}{|c|c|c|c|c|c|}
\hline Dimension & Description & Min Value (M) & Max Value $(X)$ & Average (E) & $\begin{array}{l}\text { Standard } \\
\text { Deviation }\end{array}$ \\
\hline \multirow{3}{*}{$\begin{array}{l}\text { Commitment } \\
\text { persistence }\end{array}$} & Bear pressure and changes & 2.00 & 5.00 & 4.0500 & .83333 \\
\hline & Persist whatever the difficulties are & 2.00 & 5.00 & 4.1200 & .91320 \\
\hline & Sacrifice what individuals own for startup & 1.00 & 5.00 & 4.0500 & .86894 \\
\hline \multirow{3}{*}{$\begin{array}{l}\text { Teamwork } \\
\text { cooperation }\end{array}$} & Rules and systems to regulate employees & 2.00 & 5.00 & 4.2000 & .61955 \\
\hline & Lead, stir and supervise employees & 2.00 & 5.00 & 4.2000 & .76541 \\
\hline & Employee cohesion & 3.00 & 5.00 & 4.2200 & .66027 \\
\hline \multirow{5}{*}{$\begin{array}{l}\text { Continuous } \\
\text { learning }\end{array}$} & Summarize experience in startup and operation & 2.00 & 5.00 & 4.2700 & .76350 \\
\hline & Learn experience from others & 2.00 & 5.00 & 4.1800 & .75719 \\
\hline & Actively learn knowledge and skills for startup & 2.00 & 5.00 & 4.1600 & .82536 \\
\hline & Apply knowledge and skill in startup & 2.00 & 5.00 & 3.8600 & .81674 \\
\hline & Unceasingly raise new ideas and methods & 2.00 & 5.00 & 3.6200 & 1.00282 \\
\hline
\end{tabular}

\section{CONCLUSION}

Based on the research results mentioned above, we can draw a conclusion as follows:

- Individual social practice and work experience are main sources for startup competence of returned rural migrant workers, the startup training organized by local authorities bring few help to the startup. With regard to the coming startup training, the authorities should do what rural migrant workers need and provide more chances for startup training, actually improving the startup competences through startup training.
- At the initial period of startup, the returned rural migrant workers have inherent deficiency, poor in corporate organization and operation, client service, interaction with clients, commitment persistence, teamwork cooperation and continuous learning. During the startup practice, the returned rural migrant workers have their competences such as client service, resource integration and utilization, organization and operation obviously improved.

- Though returned rural migrant workers are full of confidence in self-evaluation, yet most of the startups are a kind of simulation, which are in the lack of independent innovation. The weakness in applying and creating knowledge and skills in the continuous learning has been a barrier for the continuous 
improvement of startup competence, restricting the innovative development level of returned rural migrant workers in the future.

\section{REFERENCES}

[1] Bird B. Towards a theory of entrepreneurial competency [J]. Advances in Entrepreneurship, Firm Emergence and Growth,1995,2(1):51-72

[2] Chen C C, Greene P G, Crick A. Does entrepreneurial self-efficacy distinguish entrepreneurs from managers? [J]. Journal of Business Venturing, 1998, 13(4):295-316.

[3] Lewis H. A Model of Entrepreneurial Capability Based on a Holistic Review of the Literature from Three Academic Domains. [J]. Industry \& Higher Education, 2011, 25(6):429-440.

[4] Diaz-Casero J C, Hernandez-Mogollon R, Roldán J L. A structural model of the antecedents to entrepreneurial capacity[J]. International Small Business Journal, 2012, 30(8):850-872. [5]Muzychenko O. Cross-cultural entrepreneurial competence in identifying international business opportunities[J]. European Management Journal, 2008, 26(6):366-377.

[5] Lans T, Biemans H, Mulder M, et al. Self-awareness of mastery and improvability of entrepreneurial competence in small businesses in the agrifoodsector[J]. Human Resource Development Quarterly, 2010, 21(2):147-168.

[6] DENOBLE N A,JUNG D,EHRLICH S.Initiating newventures:the role of entrepreneurial self-efficacy[Z].Pa-per presented at the abson Research Conference,Bos-ton,MA:Babson College, 1999.

[7] MAN T W Y,THERESA L,CHAN K F.The compete-tiveness of small and medium enterprise:a conceptualize-tion with focus on entrepreneurial competencies[J].Jour-nal of Business Venturing,2002,17(2)123-142.

[8] Liu Guangming, Song Hongyuan, Startup of Returned Rural Migrant Workers: Characteristics, Causes and Influences [J]. Chinese Rural Economy, 2002(3): 65-71.

[9] Wang Shengyuan, Zhang Ping, Shi Yajuan, Researches on Startup of Returned Rural Migrant Workers---based on SWOT [J]. Research on Economics and Management, 2009 , 23 (10):90-93.

[10] Zhu Honggen, Kang Lanyuan, Weng Zhenlin, et al, Empirical Analysis of Factors Influencing The Startup Willing of Returned Rural Migrant Workers in a Large Laborer Output Province [J]. China Rural Survey, 2010 (5): 38-47.

[11] Zheng Shaofeng, Guo Quncheng, Factors Influencing the Decision Making in Startup of Returned Rural Migrant Workers [J]. Journal of South China Agricultural University (Social Science Edition), 2010.9(3): $9-15$. 